\title{
Analysis of industry based on resources and institutions National Desazolves case
}

\section{Análise da indústria com base em recursos e instituições caso de Desasufros Nacional}

José G. Vargas-Hernándę- Research professor. Departament of Administration University center for Economic and Managerial Sciences. University of Guadalajara. E-mail: jvargas2006@gmail.com

Gabriela Sarahi González González - Maestría en Negocios y Estudios Económicos. Centro Universitario de Ciencias Económico Administrativas. Universidad de Guadalajara. E-mail: gabi.gonzalez.gonzalez2@gmail.com

\begin{abstract}
This work aims to identify the elements necessary for the operation of enterprises engaged in waste management, especially in the company called Desazolves Nacionales; as well as the importance of formal institutions to arrive to conduct their activities legally without polluting the environment. an analysis of the industry and the resources with which account, in order to take advantage of the best way to strengthen the company looking to create jobs always looking for social responsibility is made.
\end{abstract}

\section{Resumo}

Este trabalho tem como objetivo identificar os elementos necessários para o funcionamento de empresas de gestão de resíduos, especialmente na empresa chamada Desazolves nacionais; bem como a importância das instituições formais para chegar a conduzir as suas actividades legalmente sem poluir o meio ambiente. Uma análise da indústria e dos recursos com os quais conta, a fim de aproveitar a melhor maneira de fortalecer a empresa que pretende criar empregos sempre à procura de responsabilidade social é feita.

\section{Keywords}

Strategy. Institutions. Industry. SMEs. Resources.

\section{Palavras-chave}

Estratégia. Instituições. Indústria. PME. Recursos. 


\section{INTRODUCTION}

The aim of the research is to determine how resources, industry and institutions affect the operation of the National Desazolves Company, located in the State of Jalisco. First, we talk about the background it has about pollution, the importance of MSMEs and what companies defined sector of waste management. After the problem is delimited on the question how do institutions affect industry and resources for company operation within the State of Jalisco? A review of the theoretical and empirical literature on the theories studied is made. It is contextualized about where the company was born, the services performed are mentioned; the methodology to be used, the analysis of the results, and finally, are given the conclusions and recommendations on the research.

\section{BACKGROUND OF THE PROBLEM}

Companies are defined as an economic unit of production and decisions by organizing and coordinating a series of productive factors, such as labor and capital, aims to make a profit either producing and selling products or providing services in market (Andersen, 1999). The importance of small and medium (MSMEs) economics units in the global economic context is a well proven fact, not only because they represent $95 \%$ of all enterprises in most countries of the Organization for Economic Cooperation and Development (OECD), but also because they generate a high volume of employment, which exceeds more than half of private sector employment (OECD, 2000).

Latin American countries generally rank companies according to various parameters such as employees, investment in fixed assets and / or sales. In Mexico, these businesses contribute about $64 \%$ of the total gross production, but employ only 2 out of 10 jobs, according to the National Institute of Statistics and Geography (INEGI, 2015); the growing importance of MSMEs especially in developing countries is due to their contribution to the employment and economic welfare; integrated into the enterprise, as part of the value chain, contribute to the diversification of the economy (Agyapong, 2010).

In Mexico, major obstacles and problems related to starting a business, among them are liquidity, the delegation of power, leadership of managers, finance and business continuity which can potentially cause failure of MSMEs during the first years of life (Castro, 2006). Companies dedicated to waste management and remediation services are those economic units that are dedicated to the collection, treatment and disposal of waste material both hazardous and non- 
hazardous waste; the operation of facilities for recovery of material; remediation and rehabilitation of contaminated sites; rental of portable toilets, and cleaning septic tanks (INEGI, 2015).

The importance of these companies is that according to the World Health Organization (WHO, 2014) reported that in 2012 about 7 million people died as a result of exposure to pollution because it is the health environmental risk the world's most important. If it is taken into account that has a rapid urbanization, cities face a growing demand for water and sanitation services for both households and industries.

The United Nations (ONU, 2010) mentions that they have the necessary knowledge, experience and technology to combat pollution and waste management, but it is essential to include these issues on national, regional and international agendas requiring coordination between sectors and between different local authorities and governance changes that lead to a more sustainable and equitable use of urban water resources.

\section{DEFINING THE PROBLEM AND RESEARCH QUESTION}

In 2015 the INEGI reported that the habits of consumption of natural resources and environmental degradation came close to generating $5.7 \%$ environmental costs of gross domestic product (GDP). Mention that the amount of public sector expenditures for environmental protection was about 149 billion pesos which represented about $1.0 \%$ of GDP. In contrast, total costs consist of depletion and environmental degradation they approached the 910 billion pesos, which gave an environmental deficit of 761 billion pesos.

Companies dedicated to service waste management and waste and remediation services are vital, both in Mexico and in the State of Jalisco, as they help to fight pollution seeking to balance the effects that have in the process of industrial, agricultural and domestic activities. So, this research attempts to answer how do institutions affect industry and company resources for operation within the State of Jalisco?

\section{REVIEW OF THE THEORETICAL AND EMPIRICAL LITERATURE}

a) Theory of resources

Wernerfelt (1984) defines resources as the assets, both tangible and intangible, that are linked to the company semi-permanently as brands, own 
technological knowledge, the use of personal skills, business contacts, efficient procedures, the capital, etc. Business enterprise is defined as an administrative organization and a collection of productive resources. The overall purpose of the business enterprise is to organize the use of their "own" resources, along with other resources acquired from outside the company for the production and sale of goods and services at a profit (Mahoney, 2012); Penrose also argues that own resources are never entering the production process, but only the services that the resource can perform.

The resources lie in a set of potential services defined regardless of use, while services cannot be so defined, the service involves a function or activity; It is largely in this distinction that can be found the source of the uniqueness of each individual company. The company can be seen as a collection of productive resources where the choice of the different uses of these resources over time is determined by administrative decision. Physical resources of a company consist of material things as facilities, equipment, land and natural resources, raw materials, intermediate products, waste products and byproducts, and even stocks of finished unsold products. There are also intangible resources available in a company like unskilled and skilled, clerical, administrative, financial, legal, technical and management personnel work.

b) Industry-based theory

The industry-based theory can be defined as a group of firms producing similar goods or services together (Peng, 2012). A popular and effective in reviewing the performance of the industrial environment, the model is based on Porter's five forces (Daft, 2010) strategy.

\section{1) The threat of new competitors}

In a sector can create pressure for the establishment of organizations, which might need to hold down prices or increase their level of investment, the entry of new competitors. Also it depends largely on the amount and extent of possible obstacles, as is the cost (Daft, 2010).

\section{2) The bargaining power of suppliers}

It refers to the ability they have to raise prices and / or reduce the amount of goods and services; if the supplier industry is dominated by a few firms they may have the advantage when negotiating (Peng, 2012). 


\section{3) The bargaining power of buyers}

It can influence when having a small number of buyers leading to a strong bargaining power. They can force down prices, demand better quality or service, and increase costs for provider organization (Daft, 2010).

\section{4) The rivalry between competitors}

It refers to the intensity that has the competence. To study this area must be known if it has many competitors or are balanced, slow growth of the industry, which are storage costs and fixed costs, which is the differentiation or cost to change, the bet to the strategy and barriers to exit (Peng, 2012).

\section{5) The threat of substitute products}

It is known as the power of alternative or substitute for the services or products of the company that may be affected in costs, new technology, social trends that they affect the customer loyalty as well as other changes environmental (Daft, 2010).

Porter added in 1990 to related industries and support as affecting the competitiveness of the industry, some call them complementary defined as that firm which sells products that add value to products of the industry focal (Peng, 2012).

\section{c) Theory of institutions}

Institutions can be defined as humanly planned constraints that structure human interaction; the institutional framework is made of both formal and informal organizations that seek to govern individual behavior and of the firm. Formal institutions are those that include laws, regulations and rules, as the regulatory and coercive pillar of governments. Informal institutions include norms, culture and ethics; It gives support with training pillar referred as values, beliefs and actions of other relevant players that have influence on the behavior of individuals or focal firms; They are also supported by the cognitive pillar referring to the values and inner beliefs that assume and which also guide the behavior of individuals and firms (Peng, 2012).

The interactions between institutions and companies that reduce transaction costs are those that give way to economic activity, as institutions are not static so they are adapting and changing as will be necessary for this 
purpose require transitions institutions defined by Peng (2012) as those great and fundamental changes that are introduced to both formal and informal rules of the game that affect organizations as players spread around the world, but especially in emerging economies.

\section{CONTEXTUAL FRAMEWORK}

The state of Jalisco has an area of 80.137 square kilometers, is located in western Mexico which borders the states of Nayarit, Zacatecas, Aguascalientes, Guanajuato, San Luis Potosi, Michoacán and Colima. In addition, a considerable portion of its territory is bordering the Pacific Ocean. Jalisco's capital is Guadalajara, but today is a great metropolis, together with the municipalities of Zapopan, San Pedro Tlaquepaque, Tonalá, Tlajomulco de Zuniga, El Salto, Ixtlahuacán de los Membrillos and Juanacatlán which integrate a large conglomerate that makes Guadalajara Metropolitan Area is the most important in Mexico.

The company called National Desazolves is a micro company that has 5 years of life. It is located in the city of Zapopan, Jalisco primarily serving the metropolitan area of the state and nearby municipalities. This company has a wide range of services offered by builders and land developers, maquiladoras and food industries, shopping malls, city halls and state secretaries, as well as dwellings; between commercial activities carried out they can be listed as follows:
a) Silt removal of septic tanks, sumps absorption wells, storm drains.
b) Suction heavy mud.
c) Uncover commercial and industrial drains.
d) Preventive survey pipes.
e) Video robotized inspection.
f) Income vactor trucks and vacuum to industries and fractionators.
g) Rent of portable toilets.
h) Service hookah

\section{RESEARCH METHODS}

For this work a descriptive research on how institutions come to influence the operation of these businesses is used in the study of the case of National Desazolves for how both formal and informal institutions and industry influence the operation of these companies in the State of Jalisco, in addition to the resources that accounts. 


\section{ANALYSIS OF RESULTS}

The company has financial resources; human, organizational, physical and technological capital reputation and innovation (see Table. 1).

Table 1. Physical and intangible resources

\begin{tabular}{l|l}
\hline Type of resources & Resources with which accounts \\
\hline Financial & $\begin{array}{l}\text { Has a good financial situation with bank accounts. Uses bank } \\
\text { loans for investment in technological equipment. }\end{array}$ \\
\hline Human capital & $\begin{array}{l}\text { Director and operational staff are considered intangible } \\
\text { resources because of the knowledge they have to perform } \\
\text { activities. The operating staff is demonstrating good execution } \\
\text { on tasks. They do not hire employees without experience in the } \\
\text { field to avoid training time. }\end{array}$ \\
\hline $\begin{array}{l}\text { Organizational } \\
\text { architecture }\end{array}$ & $\begin{array}{l}\text { The main partnership with suppliers is the shop that repairs and } \\
\text { checks the computer constantly to not incur on higher expenses } \\
\text { in addition to make repairs quickly. }\end{array}$ \\
\hline Organizational & $\begin{array}{l}\text { There is no formal organizational structure; however, operators } \\
\text { know who to report the results of services, and technical } \\
\text { problems. }\end{array}$ \\
\hline Physical & $\begin{array}{l}\text { The geographical area where is located help and support making } \\
\text { faster tasks, the proximity of offices and the pension with } \\
\text { Treatment Plant White River Río Blanco allows the company to } \\
\text { discharge early without investing too much time. }\end{array}$ \\
\hline Technology & $\begin{array}{l}\text { Its vehicle fleet is broad for the various services it offers, besides } \\
\text { its own. Plans to renovate the team are giving according to the } \\
\text { needs that are on the market. }\end{array}$ \\
\hline Innovation & $\begin{array}{l}\text { Innovation of tangible resources is not currently performed due } \\
\text { to the degree of investment involved. On the side of intangible } \\
\text { resources, the application is very low because the technical } \\
\text { knowledge gained through some training invested in the search } \\
\text { for troubleshooting technical-operational nature. }\end{array}$ \\
\hline Reputation & $\begin{array}{l}\text { The company has a good reputation in the market that works } \\
\text { through human capital that has; It is working on positioning } \\
\text { a brand image and status in the market because it is a newly } \\
\text { established company. }\end{array}$ \\
\hline
\end{tabular}

Source: Own elaboration.

Most of the resources are physical and human capital; innovation in technology is almost nil because the equipment needed to perform the services is imported from the United States, as manufacturers are located in that country and try to imitate manufacturing equipment investment of both money is needed 
as strong capital for a company like this micro or small size is difficult to achieve, so the bargaining power of technology providers is high.

Formal institutions have broad power over these businesses, first, recourse to the Constitution of the United Mexican States, in Article 4 is established as an individual guarantee and fundamental right of everyone, enjoying an environment suitable for development and welfare thus determining the State's obligation and the powers that make it, to create the mechanisms and legal instruments that lead to the guarantee. For National Desazolves can operate needs to comply with the Regulations of the Law on Waste Management of the State of Jalisco, where the requirements that must be met before the Ministry of Roads and Transport, Ministry of Environment and Territorial Development mentioned, Intermunicipal Water system and Sewerage (see Table. 2).

Table 2. Institutions

\begin{tabular}{|c|c|c|}
\hline Institution & Granting permit & Time it takes \\
\hline $\begin{array}{lll}\text { Secretary of Roads and } \\
\text { Transport Jalisco State } \\
\text { (Secretaria de Vialidad y } \\
\text { Transporte del Estado de } \\
\text { Jalisco) }\end{array}$ & $\begin{array}{l}\text { Permit to allow circulation of } \\
\text { transporting waste collection } \\
\text { services special driving. }\end{array}$ & $\begin{array}{l}\text { The resolution of the } \\
\text { permit is } 15 \text { business } \\
\text { days. }\end{array}$ \\
\hline $\begin{array}{l}\text { Secretary of Environment } \\
\text { and Territorial Development } \\
\text { (SEMADET) (Secretaria de } \\
\text { Medio Ambiente y Desarrollo } \\
\text { Territorial (SEMADET)) }\end{array}$ & $\begin{array}{l}\text { Environmental License } \\
\text { for the State of Jalisco } \\
\text { and Municipalities, for the } \\
\text { collection. }\end{array}$ & $\begin{array}{l}\text { Resolution permit are } \\
45 \text { working days. }\end{array}$ \\
\hline $\begin{array}{l}\text { Intermunicipal Water System } \\
\text { and Sewerage (SIAPA) } \\
\text { (Sistema Intermunicipal de } \\
\text { Agua Potable y Alcantarillado } \\
\text { (SIAPA)) }\end{array}$ & $\begin{array}{l}\text { Permission to download non- } \\
\text { hazardous waste treatment } \\
\text { plant. }\end{array}$ & $\begin{array}{l}\text { The resolution of the } \\
\text { permit is } 3 \text { months. }\end{array}$ \\
\hline
\end{tabular}

Source: Own elaboration

Informal institutions that are present in the company are the values of teamwork, respect, care and protection of the environment; it is committed to do the job that customers want in a timely manner agreed. It should always speak the truth to consumers when they cannot perform the activity to lie and not be able to maintain the customer loyalty. Actions are being implemented to create a culture of accountability and timeliness employees. Diamond analysis of Porter manages to define what the importance of the industry is and as what happens around them influences the decisions to be taken (See table 3, below). 


\section{CONCLUSIONS AND RECOMMENDATIONS}

After analyzing the results, it can be concluded that it is necessary to have the equipment and qualified personnel. This is decisive for the company to operate efficiently and effectively, so if it is missed one of them, is missing the services provided would be deficient. The lack of experience of the operators may lead them to incur expenses for repair of equipment if it is damaged. The investment needed to a company of this type is about 1.5 million pesos and approximately 6 months that takes for granted the permits.

Table 3. Porter's Diamond analysis

\begin{tabular}{l|l|l}
\hline Force & Conditions & Actions to combat \\
\hline Threat of new entrants & High entry barriers & Are not necessary \\
$\begin{array}{l}\text { Rivalry between } \\
\text { competitors. }\end{array}$ & $\begin{array}{l}\text { Differentiation in price and } \\
\text { quality of service. }\end{array}$ & $\begin{array}{l}\text { Improve services, advertising } \\
\text { an price and cost } \\
\text { improvement. }\end{array}$ \\
\hline $\begin{array}{l}\text { Threat of substitute } \\
\text { products }\end{array}$ & $\begin{array}{l}\text { Are practically nonexistent } \\
\text { for cleaning tanks, treatment } \\
\text { plants The survey of } \\
\text { housing can be performed } \\
\text { by plumber's drainage. }\end{array}$ & $\begin{array}{l}\text { They are not necessary, since } \\
\text { the cost for homes is high } \\
\text { compared to that accorded } \\
\text { the plumber. }\end{array}$ \\
\hline $\begin{array}{l}\text { Bargaining power of } \\
\text { customers }\end{array}$ & $\begin{array}{l}\text { Customers decide based } \\
\text { on price, quality and } \\
\text { implementation time of } \\
\text { services. }\end{array}$ & $\begin{array}{l}\text { Training in continuous } \\
\text { improvement. }\end{array}$ \\
\hline $\begin{array}{l}\text { Bargaining power of } \\
\text { suppliers }\end{array}$ & $\begin{array}{l}\text { Technology providers have } \\
\text { great bargaining power; } \\
\text { which they provide the } \\
\text { supplies have very little } \\
\text { bargaining power. }\end{array}$ & They are not necessary. \\
\hline
\end{tabular}

Source: Own elaboration.

Being a service that cannot be considered as a valuable, rare or difficult to imitate resource, companies seek to excel in competition based on giving a lower price and better quality service. National Desazolves intends to position itself as a separate company on quality, best performing services each time they are performed so that continuous improvement works to correct errors that have. Must work in positioning the brand to achieve to have a large market and become a larger, benefiting the community with better jobs and especially helping to fight pollution that occurs in the region on water resources. 


\section{REFERENCES}

AGYAPONG, D. Micro, small and medium enterprises' activities, income level and poverty reduction in Ghana - A synthesis of related literature. International Journal of Business and Management, 5(12):196. 2010.

ANDERSEN, A. Diccionario de economia y negocios. Madrid: Espasa Calpe, 1999.

CASTRO, A. M. PyME's Financiamiento, inversión y administración de riesgos (Vol. 2a.). México D.F., México: Sistemas de información contable y administrativa computarizados S.A. de C.V, 2006.

CONSTITUCIÓN POLÍTICA DE LOS ESTADOS UNIDOS MEXICANOS. México: Câmara de Senadores, 2015.

DAFT, R. L. Understanting the theory and design of organizations. Mason, Ohio. South - Western, Cengage Learning, 2010.

DESAZOLVES NACIONALES. Disponível em: <desazolvesnacionales.com>. Acesso em: 04 Mayo 2016.

INEGI. Censo Económico 2014. Instituto Nacional de Estadística Geografía e Informática INEGI, 2015.

MAHONEY, J. Economic Foundations of Strategy. Thousand Oaks, CA: Sage, 2012.

OCDE. OECD Small and Medium-Sized Enterprises: Local Strength, Global Reach, Organization for Economic Cooperation and Development. Disponível em: <www.oecd.org>, Acesso em: 04 Mayo 2016.

ONU, Agua y Ciudades, Hechos y Cifras. Organización de las Naciones Unidas, 2010 . Disponível em:<www.un.org> . Acesso em: 10 Mayo 2016.

OMS. 7 millones de muertes cada año debidas a la contaminación atmosférica. 25 marzo, 2014. Disponível em: <www.who.int>. Acesso em: 04 Mayo 2016.

PENG, M. W. Global Strategy. Cincinnati: Thomson South-Western, 2012.

REGLAMENTO DE LA LEY DE GESTIÓN INTEGRAL DE LOS RESIDUOS DEL ESTADO DE JALISCO EN MATERIA DE RECOLECCIÓN Y TRANSPORTE DE RESIDUOS DE MANEJO ESPECIAL. México: Cámara de Diputados, 2011.

WERNERFELT, B. A resource-based view of the firm. Strategic Management Journal, Vol. 5, p. 171-180, Apr. - Jun. 1984.

Texto submetido à Revista em 14.12.2016 Aceito para publicação em 05.04.2017 